\title{
Resource Regimes
}




\title{
STUDIES IN INTERNATIONAL POLITICAL ECONOMY
}

\author{
Edited by Stephen D. Krasner \\ Department of Political Science \\ Stanford University
}

\begin{abstract}
Albert O. Hirschman, National Power and the Structure of Foreign Trade

Robert A. Pastor, Congress and the Politics of U.S. Foreign Economic Policy 1929- 1976

Oran R. Young, Natural Resources and the State: The Political Economy of Resource Management

Oran R. Young, Resource Regimes: Natural Resources and Social Institutions
\end{abstract}




\section{Resource Regimes}

Natural Resources and Social Institutions

\section{Oran R. Young}

University of California Press

Berkeley Los Angeles London 
UNIVERSITY OF CALIFORNIA PRESS

Berkeley and Los Angeles, Califomia

UNIVERSITY OF CALIFORNIA PRESS, LTD

London, England

Copyright (C) 1982 bY THE REgents OF THE UNIVERSITY OF CALIFORNIA

Library of Congress Cataloging in Publication Data

Young, Oran R.

Resource regimes.

Includes bibliographical reference and index.

1. Natural resources-Economic aspects-Decision making. 2. Environmental protection-Decision making.

I. Title.

HC59.Y69 $\quad 333.7 \quad 81-16108$

ISBN 0-520-04673-4 AACR2

PRINTED IN THE UNITED STATES OF AMERICA

$\begin{array}{lllllllll}1 & 2 & 3 & 4 & 5 & 6 & 7 & 8 & 9\end{array}$ 